\title{
The Potential of Capsule Hotel Service in Semarang
}

\section{Diena Mutiara Lemy and Elisabeth Heidi}

\author{
Hospitality Management Study Program \\ Universitas Pelita Harapan Tangerang, Indonesia \\ Corresponding author: diena.lemy@uph.edu
}

\section{ARTICLE INFO}

Received

11 June 2019

Accepted

04 September 2019

Available online

30 September 2019

\section{ABSTRACT}

In the last seven years, hospitality and tourism industry becomes one of the world's fastest-growing industries (Carter, 2018). The data for this proposal are gathered from primary data (direct observation and questionnaires) and secondary data (online publications). Capsule Hotel Service provides capsule rooms for guests to stay, as well as one-stop-culinary The purpose of this feasibility research study is to see whether this business is feasible or not by looking at the marketing aspect.

Keywords : hospitality industry; culinary; service marketing mix

\section{INTRODUCTION}

\section{Background}

In the last seven years, hospitality and tourism industry becomes one of the world's fastest-growing industries (Carter, 2018). As explained by BBC (2018), one of the reasons, why this industry is growing, is because nowadays people have become more wealthy, so there is more disposable income that can be used for holiday. While hospitality industry is a broad group of businesses that provides services to customers. It is focused on the satisfaction of customers and providing specific experiences for them (Samoszuk, 2018). Semarang City, Indonesia, is now developing well, especially in the hotel industry. West region of Semarang, specifically Madukoro Street, is becoming more popular because its location which is near with the new International Airport Ahmad Yani, Semarang, as quoted from Suara Merdeka (2018). Because of that, both people from domestic and international always pass through this region. In addition, west region of Semarang also has schools, blocks of houses, and malls. However, in this region, there is no local food of Semarang, which people looking for, existed. While 
actually, one of the reason people go to Semarang is culinary (Ferdian, 2015).

Hospitality and tourism industry becomes one of many aspects that give big impacts toward the economic of a city; hence, government gives big attention to it. Therefore, there are several data below that show the growth of hospitality and tourism industry in Indonesia, especially in Semarang:

Table 1. The Gross Regional Domestic Product (GRDP) of Accommodation and Food and Beverage in Semarang per Sector

\begin{tabular}{|c|c|}
\hline Year & GRDP (Million Rupiah) \\
\hline 2013 & $3,649,245.71$ \\
\hline 2014 & $4,141,925.78$ \\
\hline 2015 & $4,553,290.74$ \\
\hline 2016 & $5,111,497.17$ \\
\hline
\end{tabular}

Source : Badan Pusat Statistik Semarang (2018)

From the table above, it can be clearly seen that the GRDP of Semarang, especially in the accomodation and food and beverage sector is increasing year by year. The definition of gross domestic product (GDP) itself is one of the main indicators used to measure the performance of a country's economy (Jordaan, 2013). In other words, one of the reasons of the growth in economic aspect of Semarang is because of accomodation and food and beverage.

Table 2. Number of Foreign and Domestic Visitor of Non-classified Hotels In Semarang

\begin{tabular}{|c|c|c|}
\hline Year & $\begin{array}{c}\text { Foreign } \\
\text { Visitor } \\
\text { (Persons) }\end{array}$ & $\begin{array}{c}\text { Domestic Visitors } \\
\text { (Persons) }\end{array}$ \\
\hline 2013 & 11 & 794.401 \\
\hline 2014 & 63 & 751.310 \\
\hline
\end{tabular}

Source : Badan Pusat Statistik Jawa Tengah (2018)

From the table above, it can be clearly seen that the number of foreign and domestic visitor of non-classified hotels in Semarang has been increasing from 2013 to 2014. It means, the need of accomodation for visitor in Semarang is also increasing. However, land price in everywhere, especially in Semarang is also increasing. That is why, a place where many people can stay together is needed now, and will be needed in the future. Therefore, the idea of Capsule Hotel is coming up nowadays.

Japan Guide (2018) stated that Capsule Hotel is a hotel which provide enclosed bed with basic amenities for less money than regular or business hotel, and usually use shared bathroom and shower room with other guests. Capsule Hotels are first introduced in Osaka in the late 1970s as a solution to a problem in Japan where workers need a place to stay before starting their new days (Drescher, 2016). Kumparan (2017) explained that Capsule Hotel opened because taxi fare is rising, which is too expensive for workers to go 
back home. At that time, the price of capsule hotel is cheaper than taxi fare as well as business hotel. Drescher (2016) also stated that in fact, capsule hotels are filling the gap in the hospitality industry where it is good because of its location, affordability, and style without compromising too much on privacy. As quoted from Kumparan (2017), in Indonesia, capsule hotel is first built in 2006, and since then, there are many capsule hotels built with their own characteristics. After popping up in Indonesia for more than 12 years, capsule hotels are becoming easier to be found in several cities such as in Bandung, Surabaya, Mojokerto, etc.

From the preliminary survey to 14 eligible sources, who have been visiting Semarang for several times, it can be clearly seen that $64.3 \%$ people go to Semarang to do culinary which is 9 out of 14 people. It means, most people like the taste of local food and traditional delicacies of Semarang. Nextly, there are 9 out of 14 people who want to try capsule hotel in Semarang, since it is a new interesting experience. Last but not least, in fact, there are 10 out of 14 people choose to stay in a hotel which is near with the airport while they can still enjoy Semarang's local food.
Table 3. What Do You Do at Semarang

\begin{tabular}{|c|c|}
\hline Activities & Percentage \\
\hline Culinary & $64.3 \%$ \\
\hline Holiday with Family & $64.3 \%$ \\
\hline Shopping & $21.4 \%$ \\
\hline Business & $14.3 \%$ \\
\hline $\begin{array}{c}\text { Choral Music } \\
\text { Ministry }\end{array}$ & $7.1 \%$ \\
\hline
\end{tabular}

Source : Data Analysis (2018)

Figure 1. Would You Like to Try Staying in a Capsule Hotel?

Source : Data Analysis (2018)

Figure 1. Do You Agree If There Is A Hotel Near With The Airport While You Can Still Enjoy Semarang's Local Food?

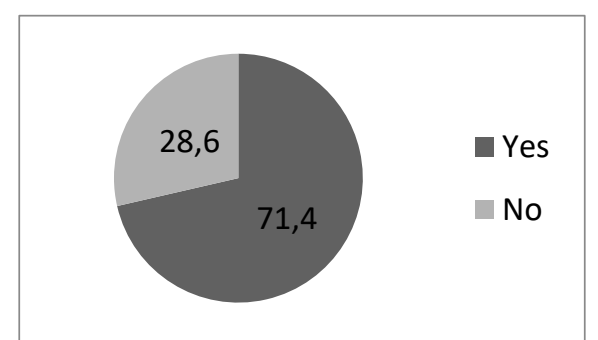

Source : Data Analysis (2018)

Capsule hotel service which is adapted several concept of hospitality industry. This capsule hotel is adopting the concept of airport hotel, because this hotel is near with the International Airport of Semarang. Not only that, the Capsule Hotel is also a transient small budget hotel since the price that is relative low, with only 40 rooms inside. In addition, this hotel is also adopting the concept of limited service hotel since this hotel offers 
guest rooms only, without meeting or function space, and limited food and beverage facilities. For the one-stopculinary, it adopts the Quick-Service Restaurant, especially Cafeteria concept where people are served from a counter and pay before eating.

\section{Research Objectives}

The purpose of this research study is to analyze every aspects that are related to the business plan of Capsule Hotel Service in Semarang. In addition, the other purpose of this business feasibility study is to measure the feasibility of the proposed business. The main objectives that will be covered in this research study are to determine whether the proposed business is feasible or not feasible to implemented by looking at 8P's marketing mix, Porter's five forces analysis, SWOT analysis, and others that may be found in the implementation.

\section{LITERATURE REVIEW}

According to Kotler and Keller (2015, p. 86), the definition of market demand itself is: "Market demand for a product is the total volume that would be bought by a defined customer group in a defined geographical area in a defined time period in defined marketing environment under a defined marketing program." It can be understood that the first thing a business should find before it knows the market demand is the customer group. The owner of a business should know whether there are many people who will buy the products or not. Morrison (2010, p. 755) stated that the definition of market potential analysis is: "Market potential analysis is a research component of a market or feasibility analysis that determines if there are enough potential customers for a new hospitality or travel business". Based on definition that is stated above, market potential analysis means analyzing who are the potential customers of a business. According to Morrison (2010, pp. 146-148), market trend analysis is defined as: "Researching new markets is a constant activity of a marketing-oriented organization. A situation analysis helps achieve new sources of customers in several different ways. The location and community analysis discovers new market opportunities arising from the site location and from cooperation with complimentary business". The information regarding market trend can be collected from data collection in the form of questionnaires.

In this research, supply aspect is very needed because demand and supply are interdependence. If there is demand from the customers, there should be also supply that will fulfill the demand of the e-ISSN: 2407-392X. p-ISSN: 2541-0857 
customers. McEachern (2013, p. 73) defined supply as the relationship between price and the number of products that is given. Supply shows how many producers are able to offer their products in the price and time that is needed. The relationship between demand and supply, as well as the supply of a business, so that a business can make the right strategies to compete with the other business, supply analysis is needed. Supply analysis that is used in this feasibility study are: SWOT analysis (Strength, Weakness, Opportunities, Threats), Five-Forces Porter, and competitor analysis.

By doing SWOT analysis, which consists of Strength, Weakness, Opportunities, and Threats, a business owner can see the situation of a business, so that he/ she can understand first the reality before they start up a business. According to Enz (2010, p. 16), SWOT analysis is defined as below: "A SWOT analysis is a tool strategists use to evaluate Strengths, Weaknesses, Opportunities, and Threats".

By doing a good evaluation of strengths, weaknesses, opportunities, and threats, a business can use its strengths and opportunities to be the adding value of a business, while the weaknesses and threats can help a business to overcome it by making a good strategy.
Michael Porter, one of strategic management expert, formulated a model that can help managers to evaluate situation and condition so they can increase the competitive advantage of their companies. According to Enz (2010, p. 649), Five Forces Porter is: "Forces that largely determine the type and level of competition in an industry and, ultimately, the industry's profit potential; they include customers, suppliers, entry barriers, substitute products or services, and rivalry among existing competitors". From the definition above, there are five things that will influence the competitive advantage of a company, which are customers, suppliers, entry barriers, substitute product or services, and rivalry among existing competitors.

1. Bargaining Power of Customers: Customers have the bargaining power to a company which can influence a decision of a company. However, there are many factors that can affect the bargaining power of customers. According to Porters (Enz, 2010: 61), the factors are:

a. They are few in number. This creates a situation in which an industry competitor can't afford to lose a customer.

b. They make high - volume (regular) purchases . High volume purchasers in the hospitality industry can often dictate contract terms, force 
price concessions, or demand special services.

c. The products they are buying are undifferentiated (also known as standard or generic) and plentiful. This means that customers can find alternative suppliers.

d. They are highly motivated to get good deals. This happens when they earn low profits or when a lot of what they buy comes from the same industry.

e. They can easily integrate backward and thus become their own suppliers. Vertical integration means that a firm moves forward to become its own customer or, in this case, backward to become its own supplier.

f. They are not concerned about the quality of what they are buying. This happens when the products or services don't influence the quality of the buyers own products or services. Because quality is not affected, customers will be interested primarily in obtaining the lowest possible price.

g. They have an information advantage when compared to the firms from which they buy products and services. Information creates bargaining power.

h. They are well organized. Sometimes weaker customers come together to increase their bargaining power.

2. Bargaining Power of Suppliers: Suppliers have an important role http://ojs.unud.ac.id/index.php/eot for a company, because when they increase their price, it will affect the profit of a company (Enz, 2010: 63). Suppliers can give a negative impact toward a company if they are not able to fulfill what the company needs. For instance, if the suppliers send a low quality of a product, it will affect the quality of the company itself. Therefore, actually there are some factors that will enhance the bargaining power of suppliers, which are:

a. Suppliers are few in number, or, in the extreme case, there is only one supplier for a good or service. This limits the ability of buying organizations to negotiate better prices, delivery arrangements, or quality.

b. They sell products and services that cannot be substituted with other products and services.

c. They do not sell a large percentage of their products or services to the buying industry.

d. They have a dependent customer. In other words, the buying industry must have what the suppliers provide in order to provide its own services.

e. They have differentiated their products or in other ways made it costly to switch suppliers.

f. They can easily integrate forward and thus compete directly with their former buyers.

3. Entry Barriers: Because there are many hotels that are built nowadays, as a new business, e-ISSN: 2407-392X. p-ISSN: 2541-0857 
Capsule Hotel should have the uniqueness so it will not be easy to be copied. According to Porter (Enz, 2010: 66), there are some entry barriers that can influence competitors to entry, which are:

a. Economies of scale. Economies of scale occur when it is more efficient to provide a service at higher volume.

b. Capital requirements. Also known as start - up costs, high capital requirements can prevent a small competitor from entering an industry.

c. Product differentiation. Established firms enjoy a loyal customer base, which comes from many years of past advertising, customer service, loyalty programs, word of mouth, or simply being one of the first competitors in a particular market.

d. High switching costs. Switching costs can serve as an entry barrier to protect competing firms.

4. Substitute Product or Services: According to Porter (Enz, 2010: 68), substitute products can also influence the level of industry competition. There can be substitute products if there is another competitors who launch the similar product with lower price and various type of products. There must be a differentiation between our product and other products so that people will not easily change to other company's products.
5. Rivalry Among Existing Competitors: Usually, a business in the same industry has competitors, which is called rivalry among existing competitors. According to Porter (Enz, 2010: 64), some major forces that will lead to high levels of competition are:

a. There are many competitors in the industry, and none of them possess a dominant position. In a situation of pure competition, organizations must work hard to maintain their positions, because customers have so many options.

b. The industry is growing slowly. Slow industry growth leads to high levels of competition, because the only way to grow is through taking sales or market share from competitors.

c. Products in the industry are not easily differentiated (i.e., they are standard or generic).

d. High fixed costs exist. High fixed costs mean that firms are under pressure to increase sales to cover their costs and eventually earn profits.

According to Morrison (2010, p. 748 ), competitor is an organization which has similar product or services to fulfill the same market needs. According to Morrison (2010, p. 141), competitor is: "These are usually business in the local community with a large share of the target markets identified in the market potential analysis".

a. Direct Competitor: Morrison stated that direct competitor is organization service with e-ISSN: 2407-392X. p-ISSN: 2541-0857 
competing or similar product to fulfill the needs of some customers (2010, p. 748). Organizations in this sector will compete directly.

b. Indirect Competitor: Indirect competitors are competitors who sell similar product or services that can be a substitution that can fulfill the same needs but with different product or services, in the same area.

According to Morrison (2010, p. 749), marketing mix is defined as "Product, place, promotion,price, people, packaging, programming, and partnership - the eight elements of hospitality and travel organization's marketing mix" People usually called it as Marketing Mix 8P's.

1. Product: Morrison (2010, p. 761) stated that product is a series of marketing service and facilities that is given by the hospitality and tourism industry to the consumers

2. Price: Morrison (2010, p. 763) stated that price is a monetary value from a provided service which determine the financial of a company

3. Place (Distribution): According to Morrison (2010, p. 760), place is defined as "The plan that the organization makes to allow it to work with other complementary groups in the distribution channel". Morrison (2010, p. 427) also explained that there are two distribution channels available, which are direct and indirect distribution. Direct distribution is the channel of distribution when an organization is the only one who responsible to promote, reserve, and provides services to customers directly, without any intermediaries. Indirect distribution involves the organization promotes, reserve, and provide services to customers with the help and service of intermediaries.

4. Promotion: As quoted from Morrison (2010, p. 764), promotion is a technique to sell avalaible services, while promotion mix is a combination of advertising, personal selling, sales promotion, merchandising, public relation and publicity which is done by an organization in a specific period of time.

5. People: According to Morrison (2010, p. 762), people is all employees in an organization who give services to the guests and also the guest itself.

6. Packaging: According to Morrison (2010, p. 762), packaging is a combination between service compliments and related services, which become an offered price.

7. Programming: As quoted from Morrison (2010, p. 762), programming "the development of special activities, events, or programs to increase customer spending or give added appeal to a package or other hospitality/ travel service"

8. Partnership: According to Morrison (2010, p. 762), partnership is "cooperative promotions and other cooperative marketing efforts by hospitality and travel organization". 


\section{METHODOLOGY}

There will be several data collecting methods that are applied in this research. The primary data will be gathered from questionnaires. According to Sekaran and Bougie, the definition of primary data is those data that are collected for the first time by the researcher for the specific purpose of the study (2016, p. 38). In other words, primary data are data that the researchers get directly from the source.

Questionnaires will be used to know the respondents' opinions about the idea of Capsule Hotel Service in Semarang, because the writer needs insights and feedback to develop the idea itself. Ho (2014, p. 336) mentioned that the way to determine number of respondents is by multiple the number of questions in the marketing mix with five (in this feasibility study, there are 45 questions in the marketing mix), so 225 respondents are needed.

Based on statement above, the minimum sample size required for Potential of Capsule Hotel Service in Semarang study is 225 respondents, since the distributed questionnaires contain 45 questions on the marketing mix section, which means that 45 questions times five equals 225. The number of distributed hard copy questionnaires are 90 booklets, and the others are using electronic questionnaires (via Google Form). Out of 90 booklets, there are 87 valid responses and 3 invalid responses, while from the electronic questionnaires, there are 144 valid responses. Therefore, there are 231 valid responses gathered from booklet and electronic questionnaires

In this research, personally administered questionnaires will be distributed to the respondents. Respondents for this questionnaire are ranging for people that are 17 to 45 years old. The questionnaires respondents are people who oftenly go to Semarang either for holiday or business purposes. The questionnaires will be shared through online and offline.

According to Sekaran, there are some principles of measurement to be followed to ensure that the data collected are appropriate to test our hypotheses, such as scaling techniques and assessment of reliability and validity of the measures used (2016, p. 150). "Goodness of data", as Sekaran stated, is assessed through tests of validity and reliability. Validity establishes how well a technique, instrument, or process measures a particular concept, and reliability indicates how stably and consistently the instrument taps the variable (2016, p. 150).

The questionnaire will consists in two parts, first part was asking about the e-ISSN: 2407-392X. p-ISSN: 2541-0857 
respondents profile and marketing mix, which is divided into 8 points: product, price, place, promotion, people, physical evidence, packaging, and partnership. In this part, the respondents will answer using likert scale with a six-point scale with the following explanation: $1=$ Very Disagree, 2 = Disagree, $3=$ Slightly Disagree, 4 = Slightly Agree, 5 = Agree, 6 $=$ Very Agree. The validity and reliability of the questionnaires should be tested and checked correctly.

\section{RESULTS AND DISCUSSION}

Table 4. Questionnaire Results on Respondent's Profile

\begin{tabular}{|c|c|c|c|c|}
\hline \multirow[b]{2}{*}{ No } & \multirow[b]{2}{*}{ Questions } & \multirow[b]{2}{*}{ Options } & \multicolumn{2}{|l|}{ Result } \\
\hline & & & $\begin{array}{l}\text { Frequency } \\
(\mathbf{N}=\mathbf{2 3 1})\end{array}$ & $\begin{array}{l}\text { Percentage } \\
(\%)\end{array}$ \\
\hline \multirow[b]{2}{*}{1} & \multirow[b]{2}{*}{ Gender } & Male & 92 & 39.8 \\
\hline & & Female & 139 & 60.2 \\
\hline \multirow{6}{*}{2} & \multirow{6}{*}{ Age } & $17-22$ & 162 & 70.1 \\
\hline & & $23-28$ & 40 & 17.3 \\
\hline & & $29-34$ & 8 & 3.5 \\
\hline & & $35-40$ & 6 & 2.6 \\
\hline & & $41-46$ & 5 & 2.2 \\
\hline & & $>46$ & 10 & 4.3 \\
\hline \multirow{5}{*}{3} & \multirow{5}{*}{ Domicile } & Semarang & - & - \\
\hline & & Jakarta & 107 & 46.3 \\
\hline & & Java Island & 52 & 22.5 \\
\hline & & $\begin{array}{l}\text { Outside of } \\
\text { Java Island }\end{array}$ & 11 & 4.8 \\
\hline & & Others & 61 & 26.4 \\
\hline \multirow{3}{*}{4} & \multirow{3}{*}{$\begin{array}{l}\text { Marital } \\
\text { Status }\end{array}$} & Single & 198 & 85.7 \\
\hline & & Married & 32 & 13.9 \\
\hline & & Others & 1 & 0.4 \\
\hline \multirow{7}{*}{5} & \multirow{7}{*}{$\begin{array}{l}\text { Educational } \\
\text { Background }\end{array}$} & $\begin{array}{l}\text { Junior High } \\
\text { School }\end{array}$ & 2 & 0.9 \\
\hline & & $\begin{array}{l}\text { Senior or } \\
\text { Vocational } \\
\text { High School }\end{array}$ & 100 & 43.3 \\
\hline & & Diploma 1-3 & 15 & 6.5 \\
\hline & & $\begin{array}{l}\text { Diploma 4/ } \\
\text { Bachelor } \\
\text { Degree }\end{array}$ & 105 & 45.5 \\
\hline & & $\begin{array}{l}\text { Master } \\
\text { Degree }\end{array}$ & 7 & 3 \\
\hline & & $\begin{array}{l}\text { Doctoral } \\
\text { Degree }\end{array}$ & 1 & 0.4 \\
\hline & & Others & 1 & 0.4 \\
\hline \multirow{4}{*}{6} & \multirow{4}{*}{ Occupation } & Student & 154 & 66.7 \\
\hline & & Housewife & 4 & 1.7 \\
\hline & & Entrepreneur & 26 & 11.3 \\
\hline & & $\begin{array}{l}\text { Private } \\
\text { Employees }\end{array}$ & 42 & 18.2 \\
\hline
\end{tabular}

\begin{tabular}{|c|c|c|c|c|}
\hline & & Others & 5 & 2.1 \\
\hline \multirow{5}{*}{7} & \multirow{5}{*}{$\begin{array}{l}\text { Income/ } \\
\text { month }\end{array}$} & $\begin{array}{l}<\quad \mathrm{Rp} \\
5.000 .000,-\end{array}$ & 142 & 61.5 \\
\hline & & $\begin{array}{l}\mathrm{Rp} \\
5.000 .001- \\
\mathrm{Rp} \\
7.500 .000\end{array}$ & 37 & 16 \\
\hline & & $\begin{array}{l}\mathrm{Rp} \\
7.500 .001- \\
\mathrm{Rp} \\
10.000 .000\end{array}$ & 18 & 7.8 \\
\hline & & $\begin{array}{l}\text { Rp } \\
10.000 .001 \\
-\quad r \quad \mathrm{Rp} \\
12.500 .000\end{array}$ & 11 & 4.8 \\
\hline & & $\begin{array}{l}>\mathrm{Rp} \\
12.500 .001\end{array}$ & 23 & 10 \\
\hline
\end{tabular}

Based on the quetionnaire result above, it is shown that the majority of the respondents are as followed:

1. 139 respondents $(60,2 \%)$ are female, while the other 92 respondents $(39,8 \%)$ are male. Although there are more female respondents, the target market of Capsule Hotel are male and female.

2. 162 respondents $(70,1 \%)$ are aged in the range of 15-22 years old and 40 respondents $(17,3 \%)$ are aged from 23-28 years old. Supported by previous data in Table 5 (Population by Group Age of Semarang 2015), the target market of Capsule Hotel is aged from 1740 years old.

3. 107 respondents $(46,3 \%)$ reside in Jakarta and 52 respondents $(22,5 \%)$ respondents reside in Java Island. The primary target market is people from outside Semarang area.

4. 198 respondents $(85,7 \%)$ are still single, which are the main target of a capsule hotel, since Capsule Hotel provides single room (for one person only) more than the deluxe room (for one or two person). 
5. 105 respondents $(45,5 \%)$ are from Diploma 4/ Bachelor Degree, which means that they have the buying power to stay in Capsule Hotel. In addition, 100 respondents $(43,3 \%)$ are from Senior High School which are also the secondary target market, since they can visit Semarang with their school friends.

6. 154 respondents $(66,7 \%)$ are students and 42 respondents $(18,2 \%)$ are private employees, which are one of target market of Capsule Hotel.

7. 142 respondents $(61,5 \%)$ have a monthly income of less than $\mathrm{Rp}$ 5.000.000. This may result the respondents' buying power since Capsule Hotel is a low budget hotel.

Table 5. Questionnaire Results on Market's Condition

\begin{tabular}{|c|c|c|c|c|}
\hline No & Aspect & Description & $\mathbf{N}$ & $\%$ \\
\hline \multirow[t]{4}{*}{1} & \multirow{4}{*}{$\begin{array}{l}\text { Frequency of } \\
\text { going to } \\
\text { Semarang in } 1 \\
\text { month }\end{array}$} & $1-2$ times & 96 & 4.8 \\
\hline & & 3-4 times & 8 & .5 \\
\hline & & 4-5 times & 2 & .9 \\
\hline & & $>5$ times & 5 & 0.8 \\
\hline \multirow[t]{4}{*}{2} & \multirow[t]{4}{*}{$\begin{array}{l}\text { Accompaniment } \\
\text { to go to } \\
\text { Semarang }\end{array}$} & $\begin{array}{l}\text { Friend/ } \\
\text { Business } \\
\text { Partner }\end{array}$ & 2 & 6.8 \\
\hline & & Family & 37 & 9.3 \\
\hline & & $\begin{array}{l}\text { Single } \\
\text { Traveler }\end{array}$ & 9 & 2.6 \\
\hline & & Others & 3 & .3 \\
\hline \multirow[t]{4}{*}{3} & \multirow{4}{*}{$\begin{array}{l}\text { Time usually } \\
\text { spent in } \\
\text { Semarang }\end{array}$} & 1-2 nights & 02 & 4.2 \\
\hline & & 3-4 nights & 3 & 0.3 \\
\hline & & 5-6 nights & & .9 \\
\hline & & $>6$ nights & 7 & 1.7 \\
\hline \multirow[t]{2}{*}{4} & \multirow[t]{2}{*}{$\begin{array}{l}\text { Expenses to } \\
\text { stay in hotel per } \\
\text { room per night }\end{array}$} & $\begin{array}{l}\text { Rp } 100.000 \\
-\mathrm{Rp} \\
200.000\end{array}$ & 6 & .9 \\
\hline & & Rp 200.000 & & \\
\hline
\end{tabular}

http://ojs.unud.ac.id/index.php/eot

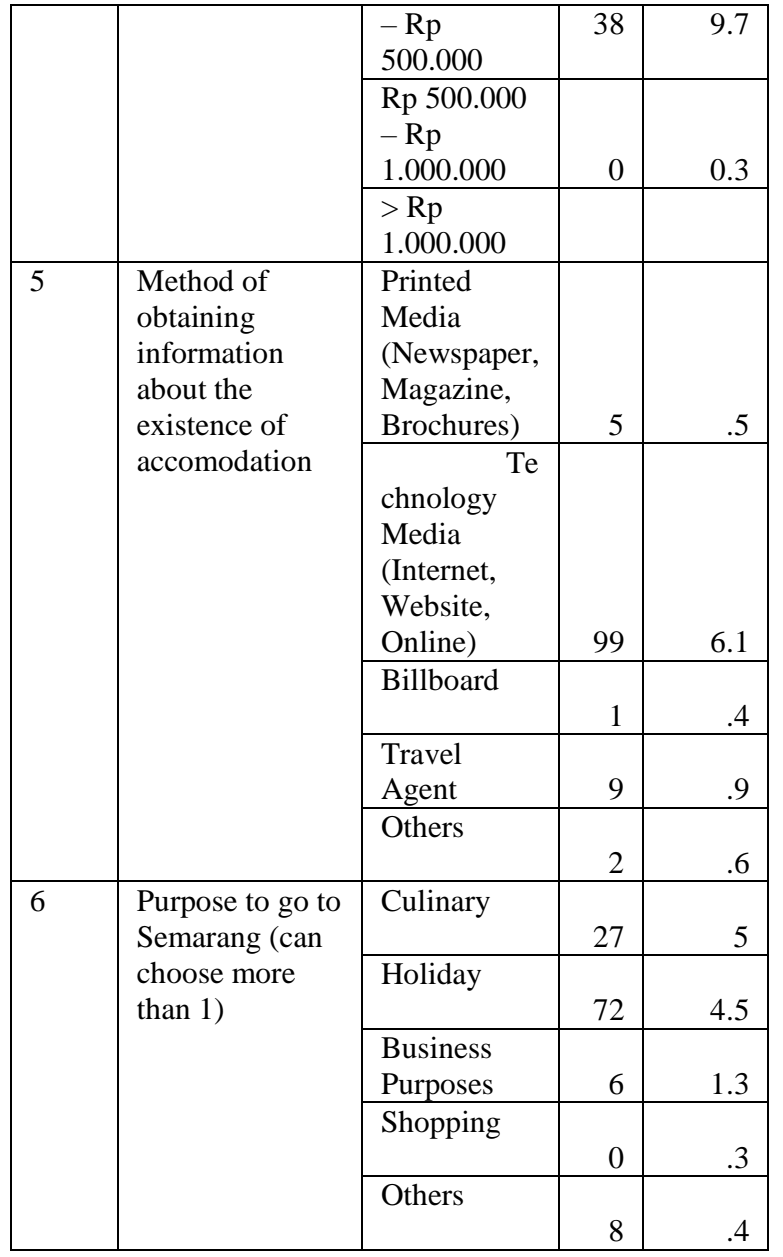

Based on the quetionnaire result in table 8 , it can be inferred that the majority of the respondents are as followed:

1. 196 respondents $(84.8 \%)$ go to Semarang 1-2 times a month. This result may show the respondent's frequency of purchase for Capsule Hotel products.

2. 137 respondents $(59,3 \%)$ go to Semarang with their family. This result may indicate the atmosphere that needs to be created in Capsule Hotel

3. 102 respondents $(44,2 \%)$ stay in Semarang for 1-2 nights and 93 respondents $(40.3 \%)$ stay in e-ISSN: 2407-392X. p-ISSN: 2541-0857 
Semarang for 3-4 nights. This may indicates the length of stay in Capsule Hotel 138 respondents (59,7\%) spend Rp 200.000 - Rp 500.000 per room per night and 70 respondents (30,3\%) spend $\mathrm{Rp}$ 500.000 - Rp 1.000.000 per room per night. This may indicate the average expenses the respondents are willing to pay in Capsule Hotel

4. 199 respondents $(86,1 \%)$ are obtaining information about existence of accomodation through online. This result may show the most effective way to promote Capsule Hotel

5. 172 respondents $(74,5 \%)$ are going to Semarang for holiday and 127 respondents $(55 \%)$ are going to Semarang to do culinary. This result may indicate that Capsule Hotel is the right place to stay, where people can do holiday and culinary in the same time.

According to Sekaran and Bougie (2013, p. 223), reliability is the indication of the stability and consistency with which the instrument measures the concept and helps to assess the "goodness" of a measure. Sekaran and Bougie (2013, p. 290) stated that to measure reabilities, it can be seen from the cronbach's alpha. If the reliabilities less than 0.60 are considered to be poor, those in the 0.70 http://ojs.unud.ac.id/index.php/eot range, acceptable, and those over 0.80 good. The calculation for Cronbach's Alpha is done automatically using IBM's SPSS (Statistical Package for the Social Science) Statistics. Table 6 shows the Cronbach's Alpha of Potential Capsule Hotel Service questionnaires result.

Table 6. Questionnaire Results on Market's Condition

\begin{tabular}{|c|c|}
\hline Cronbach's Alpha & N of Items \\
\hline 0,959 & 45 \\
\hline
\end{tabular}

Source: Data Analysis (2018)

As quoted from Widiyanto (2013, p. 188), validity can be measured by comparing the $\mathrm{r}$ table with corrected item total correlation. If the r-value is bigger than the r-table, it can be called as significant (Widiyanto: 2013, p. 188). In accordance to this theory, the value of $r$ table for 231 respondents is 0,1291 , while the corrected item total correlation from questionnaires' result of Potential Capsule Hotel Service is greater than the $r$ table $(0,354 \leq \mathrm{x} \leq 0,690, \mathrm{x}$ as corrected item total correlation), which means that this questionnaire is valid.

In the third part of the questionnaire, the respondents are asked about marketing mix, which is divided into 8 points: product, price, place, promotion, people, physical evidence, packaging, and partnership. The result from this marketing mix is expected to measure the desire of consumers so that the business can be suitable with the consumers' needs and e-ISSN: 2407-392X. p-ISSN: 2541-0857 
wants. Below is the questionnaires result of each marketing mix:

1. Product: The reliability test scores 0,926 which means the data is good and strongly reliable

2. Price : The reliability test scores 0,816 which means the data is good and strongly reliable

3. Place: The reliability test scores 0,803 which means the data is good and strongly reliable

4. Promotion: The reliability test scores 0,798 which means the data is acceptable and reliable

5. People: The reliability test scores 0,930 which means the data is acceptable and reliable

6. Packaging: The reliability test scores 0,715 which means the data is acceptable and reliable

7. Programming: The reliability test scores 0,724 which means the data is acceptable and reliable

8. Partnership: The reliability test scores 0,835 which means the data is acceptable and reliable

\section{CONCLUSION}

Based on the questionnaire results, $40,7 \%$ agree the concept of the Capsule Hotel idea. The primary target audience of Capsule Hotel are young adults to adults who are oftenly visit Semarang. Located in

West of Semarang, will be the first capsule hotel, therefore there will be no direct competitors. However, the indirect competitors include hotels that provide the usual private rooms. Products of Capsule Hotel are distributed directly and indirectly. To gain more customers, hotel will give several types of promotion and establish attractive packages and partnership.

\section{REFERENCE}

\section{Badan Pusat Statistik Kota Semarang} .bps.go.id (2018)

Badan Pusat Statistik Provinsi Jawa Tengah .bps.go.id (2018)

Badan Penyelenggara Jaminan Sosial Ketenagakerjaan (2018). Program. Home page on-line. Available from https://www.bpjsketenagakerjaan.go. id/ ; Internet; Accessed 19 November 2018.

BBC (2018). Reasons Behind the Trend in Tourism. Retrieved from http://www.bbc.co.uk/schools/gcsebi tesize/geography/tourism/tourism_tr ends_rev2.shtml ; Internet; accessed 31 July 2018.

Carter, Jack (28 March 2018). Travel \& Tourism Fastest Growing Sector Globally, says WTTC. Available from:

https://www.hotelmanagement.com. au/2018/03/28/26043/ ; Internet; Accessed 14 February 2019.

Drescher, Cynthia (10 June 2016). How Capsule Hotel Became a Global Trend. Available from: https://www.cntraveler.com/stories/2 016-06-10/how-capsule-hotelsbecame-a-global-trend ; Internet; accessed on 15 February 2019.

e-ISSN: 2407-392X. p-ISSN: 2541-0857 
Enz, Cathy A., (2010). Hospitality Strategic Management ( $2^{\text {nd }}$ ed.). USA: John Wiley \& Sons, Inc.

Ferdian, Ivan (7 August 2018). 10 Alasan Mengapa Wisatawan Wajib Berkunjung ke Semarang. Available from http://hellosemarang.com/10alasan-mengapa-wisatawan-wajibberkunjung-ke-semarang/

Ho, Robert (2014). Handbook of Univariate and Multivarlate Data Analysis with IMB SPSS, $2^{\text {nd }}$ ed. Baca Raton: Taylor and Francis Group.

Japan Guide (24 June 2018). Capsule Hotels. Available from: https://www.japan-

guide.com/e/e2025_capsule_hotels.h tml ; Internet; accessed on 15 February 2019.

Jordaan, Aneen (30 July 2013). What is GDP and Its Impact. Available from http://www.statssa.gov.za/?p=1143 ; Internet; accessed 9 August 2018.

Kotler, Philip T. And Keller, Kevin Lane (2015). Marketing Management, $15^{\text {th }}$ ed. New Jersey: Prentice Hall.

Kumparan Bisnis (2018). Tren Hotel Kapsul di RI, Dikembangkan Swasta hingga BUMN. Available from: https://kumparan.com/@kumparanbi snis/tren-hotel-kapsul-di-ridikembangkan-swasta-hingga-bumn1533295225512257636 ; Internet; accessed on 16 February 2019.

McEachern, William A. (2013). Microeconomics: A Contemporary Introduction, $10^{\text {th }}$ ed. Ohio: Thomson South-Western.

Ministry of Tourism of Indonesia (2018, July 6). Available from http://www.kemenpar.go.id/asp/detil asp?c=110\&id=4007 ; Internet; accessed 8 August 2018.
Morrison, A. M. (2010). Hospitality and travel marketing. Brantford, Ont.: W. Ross MacDonald School Resource Services Library.

Samoszuk, Savannah (2018, May 23). Hospitality Industry: Definition and Overview. Available from https://study.com/academy/lesson/ho spitality-industry-definitionoverview.html ; Internet; accessed 1 August 2018.

Sekaran Uma and Bougie Roger (2016). Research Methods for Business, $7^{\text {th }}$ ed. USA: John Wiley \& Sons.

Suara Merdeka (12 December 2018). Jalan Madukoro Dipercantik. Available from:

https://www.suaramerdeka.com/smc etak/baca/152341/jalan-madukorodipercantik ; Internet; accessed on 14 February 2019.

Walker, J. (2017). Introduction to Hospitality (7th ed.). England: Pearson.

Widiyanto, Mikha Agus (2013). Statistika Terapan Konsep \& Aplikasi SPSS. Jakarta: PT Elex Media Komputindo. 